\title{
Маріан Токар
}

Львівський регіональний інститут державного управління

Національної академії державного управління при Президентові України

\section{Діджиталізація як оптимізація взаємодії публічної влади і громадських організацій}

Дослідження фокусується на діджиталізації як публічно-управлінській інновації, яка впроваджується в публічну практику механізмами інформаційного суспільства і може бути залучена до процесів державотворення. Обгрунтована думка, що вона є забезпечувальним компонентом усього комплексу публічно-управлінських відносин. Громадська організація може взяти до уваги процедурність новітніх технологій і представити себе як постачальника соціальних послуг, приміряти на себе роль посередника/ виконавця замовлень як громадян, так і публічної влади.

Ключові слова: діджиталізаџія, діджитал-трансформація, громадські організації, органи державної влади

\section{Digitalization as an Optimization of Interaction Between Public Authorities and Non-Governmental Organizations}

\section{Marian Tokar, Lviv Regional Institute for Public Administration National Academy for Public Administration under the President of Ukraine}

The study focuses on digitalization as a public-administrative innovation, which is introduced into public practice by the mechanisms of the information society and can be involved in public-state processes. The opinion is substantiated that it is a providing component of the whole complex of public-administrative relations. A non-governmental organization can successfully adopt the procedure of the latest technologies and present itself as a service provider of social services, try on the role of mediator/executor of orders of both citizens and public authorities.

Keywords: digitalization, digital-transformation, non-governmental organizations, public authorities

$\mathrm{C}$ учасний світ важко уявити без інформаційних та цифрових технологій, які все глибше пронизують усі сфери людської життєдіяльності. Вплив інтернет-технологій, інноваційних підручних програм, накопичення і можливість використання різноманітних інформаційних баз даних значно розширюють спроможність людини оперативно й ефективно реагувати на виклики та потреби соціумного середовища. Значною мірою розширивши власний ресурсний потенціал, людина сьогодні стає дедалі вибагливішою до сфер публічних послуг, зокрема соціальних, які повинні повноцінно реалізувати інтерес буденного їі існування. Поряд із використанням традиційних підходів до державотворення Україна, крокуючи в ногу з часом, враховуючи суспільні потреби та технологічні зміни, має всі підстави застосовувати досвід провідних країн світу, де одним із пріоритетних напрямків соціумної еволюції стало використання публічно-управлін130 ських інновацій. Одним із таких модерних підходів, що формує складову сучасних нововведень у сфері публічного управління $\epsilon$ діджиталізація публічних послуг - державних і громадських. Поняття «публічні послуги» $є$ достатньо актуалізованим у національних наукових підходах і сучасними запитами суспільства, здійснюючи завдяки цьому вплив на публічну владу (Венедиктова, 2009; Драган, 2014; Ніколаєнко, 2010).

Відтак, розглядаємо діджиталізацію як публічно-управлінську інновацію, яка впроваджена в суспільну практику механізмами інформаційного суспільства і виступає забезпечувальною ланкою всього комплексу публічно-управлінських відносин. Для України це надзвичайно нова, але разом із тим актуальна проблема, покликана, на наш погляд, перезавантажити характер публічних відносин держави і суспільства й вивести на новий якісний рівень питання задоволення інтересів громадян, зокрема соціальних, і дати шанс проявити себе неурядовим інституціям. 
Отже, термін «digital» буквально перекладається як «цифровий», що відразу зорієнтовує у сферу цифрових технологій, де однією 3 важливих є роль інформації та іiї просування. Політика діджиталізації спрямована на полегшення публічної взаємодії громадян і держави (Сідей). Тому, на нашу думку, це скоріше технологія суспільна, оскільки спрямована на людину. Фактично - це царина інформаційного суспільства, а тому синер $\neg$ гетичний ефект публічної взаємодії держави та суспільства має бути спрямований на забезпечення інтересів і послуг громадян шляхом своєчасності та ефективності використання відповідних технологій. Одночасно вважаємо це інструментом публічно-управлінської інновації, оскільки він спрямований на якісне забезпечення процесу вирішення нагальних проблем громадян, пов'язаних у даному випадку зі сферою соціальних послуг.

Яку роль у цьому процесі може відіграти громадська організація? На наше переконання, вона може вдало взяти на озброєння процедурність новітніх технологій і презентувати себе сервіс-провайдером соціальних послуг, приміряти роль посередника/виконавця замовлень як громадян, так і публічної влади. Вважаємо, що важливим завданням гро-

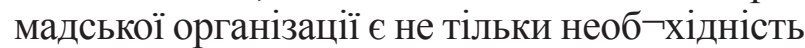
оволодіння засадами інновацій (технологічна функція), а й чітке розуміння потреб громадян (соціальна функція), уміле й ефективне спрямування своїх ресурсів на забезпечення публічної, ділової репутації й затребуваності в публічно-управлінських процесах.

Поряд із цим для дослідження ребрендингової кампанії громадської організації ближчим буде розуміння явища «діджитал-трансформаціiі» (digital-transformation) (Феоктистова), під яким розуміємо процес зміни сфери діяльності громадської організації через переосмислення стратегії iї функціонування та впровадження публічних підходів, моделей і процедур на основі діджитал-технологій. Відповідно, завдяки спеціальним підходам гро-мадської організації, що отримує замовлення на виконання певних со-ціальних послуг, збагачуватиметься їх ринок та ідентифікуватиметься цільовий замовник у громадах, які знаходяться, на ᄀприклад, у зоні із вразливою соціальною інфраструктурою. Діджитал-трансформація $\epsilon$ процесом постійним і динамічним, оскільки змушує громадську організацію відстежувати поточну інформацію з ринку послуг і шукати оптимальні варі-анти вдосконалення конкретних запитів громадян. Ігнорування ж нових технологій сьогодні може дорого обійтися громадській організації, оскільки суспільство йде в ногу з часом і супроводжує увагою тих, хто залишається в тренді. Мова йде навіть не про публічну репутацію інституції громадянського суспільства, яка і так не є на бажаному рівні. Скоріше слід говорити про життєво важливе позиціювання себе як конкурен-тоспроможного феномена, що виконує допоміжні для держави функції, реалізовуючи важливі соціальні запити суспільства. Тому громадській організації необхідно показати адекватність сприймання викликів часу, взявши на озброєння модерні підходи публічно-управлінської якості й техно-логічного прогресу.

Процес демократизації в Україні, іiі курс на децентралізацію системи публічного управління, пропаганду залучення громадян до публічного обговорення й прийняття суспільно значимих рішень змушує різноманітні інституції ефективно реагувати на вимоги соціуму та технологічного прогресу. Адже все більше інновацій знаходять своє відображення у сфері обслуговування громадян. Це свідчить про поширення технологічного прогресу та кращих новинок його ринку на суспільство, на що своєчасно має реагувати і державна політика (Токар, 2020, с. 328-329). Більше того, вважаємо, що процес діджиталізації послуг може стати чудовим прикладом синергетичної дії інституцій держави та громадянського суспільства у напрямку державотворення з прицілом на соціально справедливий характер їхніх публічних відносин. Неможливо залишити поза увагою ще один позитивний наслідок упровадження діджитал-технологій - можливість значно спростити механізм спілкування громадян із державними установами, керівниками різних державних відомств, службовцями, клерками, соціальними працівниками та ін. I нарешті, цей процес має на меті й подолання такого ганебного явища в українському суспільстві як корупція.

Усе йде до того, що панування цифрових послуг в Україні не за горами. Провідні держави світу, Свропейського Союзу сміли- 
во апробовують різні програми цифрового соціального забезпечення, запускають амбіційні проекти обслуговування населення, стимулюють публічні установи надавати широке коло адміністративних та інших послуг. Для України у цьому відношенні може бути цінним досвід сусідньої Польщі, яка лише декілька років тому обрала шлях діджиталізації державних послуг і щороку прискорює цей процес. Зокрема, той факт, що запроваджено «електронну платформу служб державного управління», свідчить про сприйняття управлінських інновацій та IT-технологій на найвищому державному рівні, а пї політика залучає до контролю й прозорості за цим процесом представників різних державних установ і громадських організацій (Литвинов). Найголовніший урок, який варто винести з цього Україні це всезагальне сприяння участі громадян у публічному управлінні та соціально-відповідальному ставленні до суспільно важливих рішень. Насправді, вірогідність поширення процесу діджиталізації публічних послуг в Україні очевидно висока. Громадський сектор ініціював проектні програми для залучення громадських активістів і лі- дерів компаній, яким цей напрям видався цікавим і перспективним (5 практичних порад: діджиталізуємо громадський сектор). Намагається не відставати й держава, якій належить бути стратегічним партнером громадськості у діджитал-трансформації. Але ефективність поступу публічно-управлінських та інших інновацій буде, вочевидь, залежати і від всезагального сприйняття, без сумніву, прогресивних процедур, які закладені у різноманітних діджитал-стратегіях. У цьому процесі також важливою буде публічна активність громадських організацій.

Отже, важливим ядром пропозиції громадської організації як соціального сервіс-провайдера має бути якісний продукт, а в даному випадку - надання різноманітних соціальних послуг. Їхня особливість полягає у зручності, цікавості й ефективності процедури. Замовник послуг має відчувати, що він не покинутий напризволяще, не залишений наодинці 3 проблемою, а йому завжди на допомогу прийде впевнена й професійна команда, яка знає що, як і коли зробити. Цю роль може виконувати суспільно-корисна громадська організація.

\section{БІБЛІОГРАФІЧНІ ПОСИЛАННЯ}

5 практичних порад: діджиталізуємо громадський сектор. Громадський простір. Відновлено 3 https://www. prostir.ua/?news=5-praktychnyh-porad-didzhy talizujemo-hromadskyj-sektor.

Венедиктова, І. (2009). Юридична природа публічних послуг. Вісник Харківського національного університету, 841, 88-91.

Драган, О. І. (2014). Організація надання публічних послуг населенню органами влади: зарубіжні практики. Державне управління: удосконалення та розвиток, 4. Відновлено з http://nbuv.gov.ua/UJRN/Duur_2014_4_3.

Ніколаєнко, К. В. (2010). Адміністративні послуги як різновид публічних послуг. Держава і право, 47, $269-274$.

Литвинов, В. Діджиталізація державних послуг на прикладі Польщі. Na chasi. Відновлено з https://nachasi. com/2018/01/31/digital-poland/.

Сідей, О. Україна у стилі digital. Юридична газета online. Відновлено 3 https://yur-gazeta.com/publications/ practice/informaciyne-pravo-telekomunikaciyi/ ukrayina-u-stili-digital.html.

Токар, М. (2020). Громадські організаиії Украӥни в системі розвитку публічно-управлінських відносин: монографія. Львівський регіональний інститут державного управління НАДУ при Президентові України. Львів: ЛРІДУ НАДУ.

Феоктистова, О. Digital transformation - что это? Ringostat Blog. Відновлено з https://blog.ringostat.com/ru/digitaltransformation-chto-eto/. 